\title{
Derleme
}

\section{Serebral palsili çocuklarda beslenme sorunları ve enerji gereksiniminin belirlenmesi}

\author{
Nüket Ünsal' ${ }^{1}$, Nilüfer Acar Tek ${ }^{2}$ \\ ${ }^{1}$ Gülhane Eğitim ve Araştırma Hastanesi, Beslenme ve Diyet Bölümü, Ankara \\ ${ }^{2}$ Gazi Üniversitesi Sağlık Bilimleri Fakültesi Beslenme ve Diyetetik Bölümü, Ankara
}

\section{$\ddot{0} \mathrm{z}$}

Beslenme desteği serebral palsili (SP)'li çocukların tedavisinde tamamlayıcı rol oynamaktadır. Serebral palsili çocuklarda kötü beslenme ve oral motor disfonksiyona bağlı olarak yetersiz protein ve enerji alımı büyüme ve gelişme geriliğine neden olabilmektedir. Bu gruptaki çocuklarda sıklıkla enerji gereksiniminde değişiklikler görülmekte ve beslenme durumunun saptanması önem taşımaktadır. Serebral palsili çocuklar için önerilen enerji ihtiyaçları nörolojik açıdan normal olan çocuklardan farklıdır. Bu hastalarda görülen ambulasyon ve motor bozukluğu durumu (türü, dağılımı, şiddeti) hareket etme durumunu ve kas tonusunu (hipertoni, hipotoni) etkileyerek dinlenme enerji harcamasını değiștirmektedir. Enerji gereksiniminin doğru olarak belirlenmesi, beslenmenin düzenlenmesinde çok önemli fakat zordur. SP'li çocuklara özel eşitlikler geliştirilmiştir. SP'li çocuklarla yapılan çalışmaların çoğunda, bu çocukların enerji gereksinimi ve dinlenme metabolizma hızının, kas kütlesindeki azalmaya bağlı olarak normal yaşıtlarına göre daha düşük olabildiği bildirilmiştir. Ağır SP'li çocukların enerji ihtiyaçları sağlıklı yaşıtlarının enerji ihtiyaçlarının yaklaşık \% 60-70'i kadardır. Serebral Palsili çocuklar için Krick'in 1992'de, Rieken' in 2011' de geliştirdiği iki eşitlik mevcuttur. Krick'in geliştirdiği metotda mobilizasyon durumu, kas tonusu, aktivite düzeyi, değișen metabolizma ve gelişimi göz önüne alınmaktadır. Rieken' in geliștirdiği eşitliklerin ilkinde bazal metabolizma hızının (BMH) belirlenmesinde sıklıkla Schofield denklemi kullanılmakta iken, diğer eşitlikte ise total vücut suyunun ölçümü kullanılmaktadır. Bu temel hesaplamaya ek olarak fiziksel aktivite düzeyi, kaba motor testi seviyesi ve SP'nin türüne göre bir düzeltme yapılmaktadır.

Anahtar Sözcükler: Serebral palsi, beslenme, enerji gereksinimi

\section{Determination of nutritional problems and energy requirements in children with cerebral palsy}

\begin{abstract}
Nutritional support plays a complementary role in treatment of children with cerebral palsy (CP). In children with $\mathrm{CP}$, malnutrition and oral motor dysfunction cause growth and development retardation due to insufficient protein and energy intake. Children in this group often show changes in energy requirements and it is important to identify nutritional status. The energy needs recommended for children with cerebral palsy are different from neurologically normal children. Ambulatory and motor impairment (type, distribution, severity) seen in these patients
\end{abstract}

Yazının geliş tarihi: 27.03.2017 Yazının kabul tarihi: 30.06.2017

Sorumlu yazar: Nilüfer Acar Tek Gazi Üniversitesi Sağllk Bilimleri Fakültesi Beslenme ve Diyetetik Bölümü, Ankara, Türkiye, Telefon: 053247533 49, e-mail: acarnil@hotmail.com 
change resting energy expenditure by affecting movement and muscle tonus (hypertonia, hypotonia). Accurate determination of the energy requirement is difficult but very important in the regulation of nutrition. Special equations for children with CP have been developed. In many studies with SP children, it has been reported that the energy requirement and resting metabolic rate of these children may be lower than normal peers due to the decrease in muscle mass. The energy requirements of children with severe $\mathrm{CP}$ are $60-70 \%$ of the energy requirements of healthy age groups. There are two equations for children with cerebral palsy; one developed by Krick in 1992, and another by Rieken in 2011. The method developed by Krick takes into account the mobility status, muscle tone, activity level, altered metabolism and development. In the first of the equations developed by Rieken, the Schofield equation is often used to determine the basal metabolic rate (BMR), while the other equation used the measurement of total body water. In addition to this basic calculation, a correction is made according to the level of physical activity, the gross motor function and type of CP.

Keywords: Cerebral palsy, nutrition, energy requirement

\section{Giriş}

Serebral Palsi (SP), çocukluk çağında sık görülen, hareket ve postürü yaşam boyu etkileyen kalıcı gelişimsel bir bozukluktur. ${ }^{1}$ Motor geriliğe (görme, işitme azlığı gibi) duyusal bilişsel (dil gelişimindeki gerilik gibi), iletişim algılama (dikkat azlığı gibi) davranış bozuklukları (hiperaktivite gibi) ve konvülziyon sıklıkla eşlik edebilir. ${ }^{2}$ Serebral palsinin dünya çapında insidansı, 1000 canlı doğumda 2-2.5 olarak belirlenmiştir. ${ }^{3}$ Türkiye'de ise, yapılan en kapsamlı çalışmada SP insidansı her 1000 canlı doğumda 4.4 olarak belirlenmiștir. ${ }^{4}$

Serebral Palsi fiziksel aktivite anormallikleri, vücut kompozisyonu ve beslenme problemleri ile karakterize ciddi çocukluk çağı hastalıklarından biridir. ${ }^{5}$ Mental ve motor bozukluklar beslenme sorunlarının sık görülmesine neden olmaktadır. Oral motor disfonksiyona bağlı olarak yetersiz protein ve enerji alımı büyüme ve gelişme geriliğine yol açmaktadır.

Serebral Palsili çocuklarda, beslenme sorunları, çocuğun motor gelișimi ve kas tonusundaki değişiklikler, yutma refleksinin olmayışı, ağız dil, dudak ve çene fonksiyonundaki bozukluklara bağlı olarak farklılıklar gösterebilmektedir. 5,6 Bütün bu faktörler, SP'li çocuklarda yavaş ve yetersiz beslenme, beslenme süresinin uzaması, aspirasyon ve salya problemleri, çocuk ve ebeveyn iletişiminde bozukluklara neden olabilmektedir.7

$\mathrm{Bu}$ çocuklarda hem nutrisyonel durumun değerlendirilmesi hem de optimal enerji ihtiyacının belirlenmesi zordur. Sağlıklı çocuklarda enerji tüketimini tahmin etmeye yarayan ve genellikle yaş, cinsiyet ve boy uzunluğunu temel alan denklemler ağır SP'li çocuklarda enerji gereksinimini fazla tahmin etmektedir. ${ }^{8}$ Enerji ihtiyacının belirlenmesinde kullanılan pek çok yöntem, nörogelişimsel bozukluğu olan çocukların ihtiyaçlarını göz ardı etmektedir. Motor bozukluğu olan çocuklarda, enerji ihtiyacının tahmini için geliştirilen eşitliklerde, fiziksel yapı ve çeşitli disfonksiyonların göz önünde bulundurulması gerektiği belirtilmektedir. ${ }^{9}$

$\mathrm{Bu}$ derlemede, SP'li çocuklarda enerji gereksiniminin belirlenmesinde kullanılan yöntemler, avantaj ve dezavantajları irdelenmiştir.

\section{Serebral Palsi Etiyolojisi ve Sinıflaması}

Serebral Palsi, doğum öncesi, sonrası veya doğum sırasında meydana gelebilir. Doğum öncesinde hastaların \%75-80'inde SP'ye neden olan hikâye bulunmaktadır. ${ }^{10}$ Sadece \%10-15'i hipoksi veya doğuma ait travma ile ilişkilidir. Prenatal risk faktörleri içeresinde; intraüterin enfeksiyonlar, plesental komplikasyonlar, çoklu doğumlar, mental retardasyon, nöbetler, hipertiroidizm, ilaç veya alkol kullanımı sayılabilir. 11

SP genel olarak motor bozukluğun tipine, etkilenmiş olan vücut kısımlarına ve etkilenme şiddetine göre sinıflandırılır.

1. Spastik tip: En sık görülen ve en fazla 
nörolojik bulgu saptanan tiptir. Spastisite etkilenen bölgeye göre değişir. Ekstremite kaslarında spastisite, gövde kaslarında tonus azlığl, denge ve koruyucu reaksiyonlarda yetersizlik, yavaş ve zor hareket, postür ve yürüme bozuklukları spastik tip SP'li çocuklarda sık görülen problemlerdir.

2. Diskinetik tip: İstem dışı ve kontrolsüz hareketin ön planda olduğu bir klinik tablodur. Değişken kas tonusu, kasların kokontraksiyonunda yetersizlik, gövde ve ekstremitelerde stabilizasyon yetersizliği, denge ve koruyucu reaksiyonlardaki yetersizlik diskinetik tip SP'li çocuklarda karşılaşılan önemli sorunlardır.

3. Ataksik Tip: Motor gerilikle birlikte erken yaşta ekstremite ve gövdede hipotoni, denge bozukluğu, yürürken belirginleşen koordinasyon bozukluğu vardır.

4. Miks tip: Nöromusküler bozuklukların birleşimi şeklinde olup, spastisite, distoni ve atetoid hareketlerle birlikte görülebilir.

Serebral palsi için kaba motor fonksiyon sinıflama sistemi (KMFSS); çocuğun kaba motor fonksiyonlarındaki becerilerini ve kısitlılıklarını temsil eden seviyeyi belirlemektir.

Her bir seviyenin genel başlıkları aşağıdaki gibidir.

Seviye 1: Kısıtlama olmaksızın yürür.

Seviye 2: Kısıtlamalarla yürür.

Seviye 3: Elle tutulan hareketlilik araçlarını kullanarak yürür.

Seviye4: Kendi kendine hareket sınırlanmıștır. Motorlu hareketlilik aracını kullanabilir.

Seviye 5: Elle itilen bir tekerlekli sandalyede taşınır.

$\begin{array}{lrr}\text { Seviye } & 1-2 \text { ambule, } & \text { seviye } 3-5 \\ \text { ambule olmayan } & \text { olarak } \\ \text { sinıflandırılmaktadır. }{ }^{12} & \end{array}$

Serebral Palsi'ye Eșlik Eden Diğer Bozukluklar ve Beslenme Sorunları

Serebral palsili çocuklarda, motor gerilikle birlikte mental problemler, epilepsi, duyu-algı bozuklukları, görme bozuklukları, işitme bozuklukları, konuşma bozukluklarl, oral-motor problemler, diş problemleri, solunum problemleri, gastrointestinal problemler görülebilmektedir. ${ }^{13}$

Beslenme problemleri, SP'li çocuklarda sıklıkla karşılaşılan önemli problemlerden biri olup, etkilenim şiddetine göre görülme oranlarında değişkenlik görülmektedir. SP'li çocuklarda yetersiz enerji alımı, besin öğesi kayıpları ve bozulmuş enerji metabolizması gibi beslenme ile ilişkili faktörler büyüme ve gelişmenin engellenmesine katkıda bulunmaktadır. Malnutrisyon, nörolojik bozukluğu olan çocuklarda yaygın olarak görülmektedir. ${ }^{14}$ Malnutrisyon nedenleri olarak aşağıdaki maddeler sıralanabilir;

1. Yetersiz besin alımı: SP'li çocuklarda besin alımı yaşıtlarına göre daha azdır. Bazı hastaların el-ağız koordinasyonunun yetersiz oluşu yiyeceklerin dökülmesine neden olabilmektedir. Çocukların büyük bir kısmı besin alımı konusunda bakım veren kişilere bağımlıdır, ayrıca açlık ve tokluk durumlarını belirtememektedirler.

2. Artmış Kayıplar: Gastroözofajial reflü, bulantı ve regürjitasyon enerji kaybınının temel kaynağıdır. Reflüye bağlı özofajit besin reddine ve besin alımında azalmaya neden olabilmektedir.

3. Değişen Metabolizma: Aynı yaş ve ağırlıktaki çocuklara göre SP'li çocuklarda dinlenme enerji harcaması daha düşüktür. Hipotonik ve yürüyemeyen çocuklar gelişim için dinlenme enerji harcamasının altında enerjiye ihtiyaç duymaktadırlar. Bununla birlikte kas tonusunun arttığı ve atetoik SP'li çocuklarda enerji ihtiyacı artmaktadır. Hafif ile orta dereceli diplejik veya hemiplejik SP'li yürüyebilen çocuklar, günlük aktivitelerini yerine getirebilmek için genellikle daha yüksek enerjiye ihtiyaç duymaktadırlar.

4. Oromotor Disfonksiyon: Oromotor disfonksiyon SP'li hastaların \%90'ını etkilemektedir ve malnurtisyon için önemli bir nedendir. Yetersiz emme, yutma bozukluğu, ağız kapanmasında zorlanmadan dolayı tükürük akması, çiğneme yeteneğinde azalma oral alımı zorlaştırmaktadır.

Günde 3-6 saate kadar uzayan ögün zamanları besinsel ihtiyaçların sağlanmasını 
zorlaștırmaktadır. SP'li çocuklarda spastisitenin şiddeti, hareketsizlik, araya giren enfeksiyonlar da malnutrisyon ve büyüme geriliğinin gelişmesine katkıda bulunabilir. ${ }^{15}$

Serebral Palsili Çocuklarda Enerji Gereksiniminin Belirlenmesi

$\mathrm{Bu}$ gruptaki çocuklarda, enerji gereksiniminde bireysel farklılıklar görülmektedir ve beslenme durumunun saptanması önemlidir. Serebral palsili çocuklar için olan öneriler, nörolojik açıdan normal çocuklar için var olan önerilerden farklıdır. Çünkü bu hastalarda bazal metabolizma hızını (BMH) değiştiren faktörler söz konusudur. Bunlardan ilki ambulasyon durumu ve motor bozukluğun durumu (türü, dağılımı, şiddeti) olup, hareket ve kas tonusunu etkilemektedir. Serebral palsili çocukların çoğunda BMH, nörolojik olarak normal olan çocuklara göre anlamlı olarak daha düşüktür. Ancak atetozlu çocuklarda nörolojik olarak normal çocuklar ile kıyaslandığında enerji gereksinimlerinin normal hatta artmış olabileceği yönünde görüşler vardır. ${ }^{16}$ Ambulasyon durumundan sonra enerji gereksiniminin diğer önemli belirleyicisi de yağsız vücut kütlesi miktarıdır. ${ }^{17}$ On üç SP'li çocuk ile yaptıkları çalışma sonucunda toplam enerji harcamasını ve BMH'nı sağlıklı çocuklardan daha düşük bulmuşlardır.

Birçok çalışma ağır motor bozukluğu olan çocuklarda enerji ve besin öğeleri alımının düşük olduğunu göstermiștir. ${ }^{18,19}$ Ağır motor bozukluğu olan çocuklarda üç günlük besin tüketim kayıtlarını değerlendirdiklerinde, önerilen besin öğesi alımının \% 59'unu aldıklarını saptamışlardır. Ayrıca, diyetle enerji alımları yaşa göre tavsiye edilenin $\% 80$ altında olan çocuklar, ağır motor bozukluğa sahip olup yaşa göre boy $\mathrm{z}$ skorları önemli ölçüde düşük bulunmuştur. ${ }^{20}$

Serebral palsili çocukların enerji gereksinimlerinin belirlenmesi için özel denklemler geliştirilmiştir. Ambule olmayan, okul çağl çocuklar için Krick'in 1992'de ${ }^{21}$ geliştirdiği bir eşitlik, Rieken' in 2011' de ${ }^{22}$ geliştirdiği iki eşitlik mevcuttur. Rieken' in geliştirdiği eşitliklerin ilkinde $\mathrm{BMH}^{\prime}$ nın belirlenmesinde sıklıkla Schofield denklemi kullanılırken, diğerinde ise total vücut suyunun ölçümü eşitlikte yer almaktadir. Bu temel hesaplamaya ek olarak fiziksel aktivite düzeyi, kaba motor testi seviyesi ve SP'nin türüne göre bir düzeltme yapılmaktadır. ${ }^{17}$

Walker ve arkadaşları ${ }^{23}$, otuz iki SP'li çocukla yaptığı bir çalışmada, enerji gereksinimini çift etiketli su yöntemi ile ölçmüşlerdir. $\mathrm{Bu}$ çalışmada ambulasyon durumunun azalmasıyla (tüm extremitelerin tutulumunda) enerji gereksiniminin de azaldığı belirlenmiștir.

Çocuklarda enerji harcamasının tahmininde kullanılan eşitlikler sonucu elde edilen tahmini enerji gereksinimleri genellikle hatalıdır çünkü bu eşitlikler aktivite düzeyi, engelli olup olmama durumu veya SP'li çocuklardan farklı olan sağlıklı çocuklara yöneliktir. ${ }^{9}$ Motor bozukluğu olan çocuklarda enerji ihtiyacının tahmini için geliștirilen eșitliklerde, fiziksel yapı ve çeșitli disfonksiyonların göz önünde bulundurulması gerektiği belirtilmektedir. Krick ve arkadaşları ise vücut yüzey alanı, aktivite düzeyi ve kas tonusu gibi faktörlerin de enerji ihtiyacını belirlemede önemli olduğunu vurgulamışlardır. Bununla birlikte bu yöntemler, bu çocuklarda ekstremite kontraktürleri ve/veya spinal deformasyonları nedeniyle ölçümü zor olan boy gibi antropometrik değerlerin doğru bir şekilde ölçülmesini gerektirmektedir. SP'li çocuklar sıklıkla normal çocuklardan daha kısa boyludur. Fiziksel yapıdaki bu önemli fark yürüme ve beslenmede bağımlı olmakla ilişsili olabilmektedir. Ancak bu bulgular henüz net değildir. $\mathrm{Bu}$ nedenle enerji ihtiyacının doğrudan indirekt kalorimetre ile ölçümü geçerli bir alternatif olabilir. Bu yöntem protein, karbonhidrat ve yağların minimal lipogenez ve ketogenez ile okside olduğu varsayılarak, oksijen tüketimi ile karbondioksit üretimi arasındaki ilişki ile substrat oksidasyonu ve böylece dinlenme enerji harcamasının ölçümüne dayanmaktadır. ${ }^{24}$

Enerji Harcamasının Tahmininde Kullanilan Yöntemler

Serebral palsili çocukların bağımsızlıklarını arttırabilmek için, ihtiyaç duydukları enerji miktarına uygun olarak beslenmeleri önemlidir. Özellikle 
quadriplejik tip SP'de sıklıkla karşılaşılan beslenme problemlerinin yol açtığı negatif enerji dengesi, düşkünlüğe neden olarak çocukların yaşam kalitesini olumsuz etkileyebilir. Ayrıca pozitif enerji dengesi de obeziteye bağlı sorunlara yol açabilir. ${ }^{25}$

Sağlıklı çocuklar için geliştirilmiş eşitlikler, SP'li çocukların enerji ihtiyaçlarını normal gereksinimden yaklaşık \%20 daha fazla gösterdiği belirtilmektedir. ${ }^{26}$ Ağır serebral palsili çocukların enerji ihtiyacı sağlıklı yaşıtlarının enerji ihtiyacının \% 6070'i kadardır. Hesaplanan tahmini enerji ihtiyacının \%75'inin verilmesiyle SP'li çocuklarda uygun büyümenin sağlandığı gösterilmiștir. ${ }^{27}$ Serebral palsili çocuklarda enerji ihtiyacını tahmin etmek için engellilere özgü genel bir eşitlik de kullanılmaktadır.

$\mathrm{Bu}$ eşitlik ile, boya göre enerji gereksinmesi hesaplanmaktadır. Ayaktan hastalarda 5-11 yaş için $14 \mathrm{kkal} / \mathrm{cm}$; bağımlı hastalarda ise $11 \mathrm{kkal} / \mathrm{cm}$ olarak hesaplanmaktadır. ${ }^{26}$ Aynı zamanda ${ }^{9}$, 5-12 yaş arası SP'li çocuklarda enerji alımını araştırdıkları çalışmada; yürüyebilen ve motor bozukluğu olan çocukların belirgin olarak daha yüksek düzeyde enerjiye ihtiyaç duydukları belirlenmiș enerji gereksiniminin $13,9 \mathrm{kcal} / \mathrm{kg}$ olarak hesaplanmasl; yürüyemeyen ve motor bozukluğu olan çocuklarda ise enerji gereksiniminin 11.1 $\mathrm{kcal} / \mathrm{kg}$ olarak hesaplanması önerilmiştir Serebral Palsili Çocukların Enerji İhtiyacının Belirlenmesinde Kullanılan Yöntemler Tablo 1'de özetlenmiștir. Vücut kompozisyonu ve motor aktiviteleri normalden farklı olan SP'li çocukların enerji gereksinimleri de farklıdır. Serebral palsili çocuklar için enerji harcamasının hesaplanmasında kullanılan eşitliklerden biri Krick Metotudur. Bu metodun temeli, bazal metabolizma hızı ve fiziksel aktivite düzeyinin belirlenmesine dayanır.

Krick metodu; Enerji gereksinimi (kkal/gün)=Bazal metabolizma hızı (BMH) x kas tonusu $\mathrm{x}$ aktivite faktörü)+ büyüme faktörü şeklinde hesaplanır.

Krick metodunda, BMH'nı bulmak için vücut yüzey alanı kullanılarak hesaplama yapmak gerekir. Bazal metabolizma hızl (BMH) hesabı = vücut yüzey alanı $\left(\mathrm{m}^{2}\right) \times$ standart metabolik hız (kcal/ $\mathrm{m}^{2} / \mathrm{sa}$ ) x 24 . Vücut yüzey alanının belirlenmesinde DuBois formülü kullanılmaktadır. DuBois formülü ile boy ve ağırlık kullanılarak vücut yüzeyi alanı hesaplanır. ${ }^{28}$ DuBois formülü28; Vücut Yüzey Alanı $=($ Ağırlık $0.425 \mathrm{~kg}$ x Boy $0.725 \mathrm{~cm}) \mathrm{x}$ 0.007184 (Tablo 1). Bulunan değer, Tablo 2'de; cinsiyet, yaş ve boya göre verilen Fleish değerleri ile standart metabolik hız değeri belirlendikten sonra, sonuç 24 saat ile çarpılarak BMH hesaplanır.

Tablo 1. Serebral Palsili Çocukların Enerji İhtiyacının Belirlenmesinde Kullanılan Yöntemler ${ }^{21,32}$

1. Krick Metodu

- Kkal/gün=(BMH $\mathrm{x}$ kas tonusu faktörü)+büyüme faktörü

- $B M H(\mathrm{kcal} / g u ̈ n)=$ vücut yüzeyi $(\mathrm{m} 2) \mathrm{x}$ standart metabolik hız(kcal/m2/sa) x 24 sa.

- Kas tonusu faktörü=azalmışsa 0.9, normal ise 1.0, artmışsa 1.1

- Aktivite faktörü=yatağa bağımlıysa 1.15 , bakıma muhtaç ise 1.2 , emekliyorsa 1.25 , yürüyebiliyorsa 1.3

- Büyüme faktörü=olması gereken

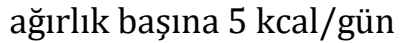

2. Boya Göre Hesaplama Metodu

- $14.7 \mathrm{kkal} / \mathrm{cm}$ motor disfonksiyonu olmayan çocuklarda

- $13.9 \mathrm{kcal} / \mathrm{cm}$ motor disfonksiyonu olan ancak yürüyebilen çocuklarda

- $11.1 \mathrm{kcal} / \mathrm{cm}$ yürüyemeyen çocuklarda

3. Dinlenme Enerji Harcamasina Dayanan Metod

- $1.1 \mathrm{x}$ ölçülen dinlenme enerji harcaması

Kas tonusu faktörlerinden

hipotonide normal kas tonusu $\mathrm{x}$ 0.9; hipertonide ise normal kas tonusu $\mathrm{x} 1.10$ olarak belirlenmiştir. Aktivite faktörü için yatağa bağımlıysa 1.15; tekerlekli sandalyeye bağımlıysa 1.20 ; emekliyorsa 1.25 ve yürüyebiliyorsa 1.30 ile çarpılmıştır. ${ }^{21}$ 
Tablo 2. Cinsiyet, yaş ve boya göre standart metabolik hızın belirlenmesi ${ }^{30}$ ( $\mathrm{X}=\mathrm{y}$ aş (yıl), $\mathrm{Y}=$ Metabolik hız(kcal $\left./ \mathrm{m}^{2} / \mathrm{saat}\right)$

\begin{tabular}{|c|c|c|c|}
\hline Grup & Yaş & $\begin{array}{l}\text { Matematiksel } \\
\text { ifade }\end{array}$ & $r^{2}$ \\
\hline $\begin{array}{l}\text { 离 } \\
\text { 产 }\end{array}$ & $1-19$ & $Y=52.96-0.77 X$ & 0.9651 \\
\hline 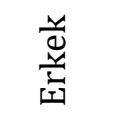 & $20-75$ & $Y=37.5-0.079 X$ & 0.9366 \\
\hline 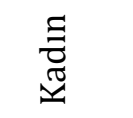 & $1-19$ & $Y=53.35-1.01 X$ & 0.9816 \\
\hline 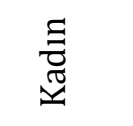 & $20-75$ & $Y=37.50-0.079 X$ & 0.9366 \\
\hline 誌离 & $1-19$ & $Y=53.09-0.88 X$ & 0.9766 \\
\hline 誌离 & $20-75$ & $Y=38.65-0.082 X$ & 0.9773 \\
\hline
\end{tabular}

Pek çok çocukta büyümeyi yakalamayı sağlamak için ek enerji gerekmektedir. Serebral palsili çocuklar tipik olarak daha kısa boylu olduklarından yaşa göre boy; antropometrik ölçümler ve büyümenin değerlendirilmesinde, kronolojik yaștan daha iyi bir ölçüttür. Payne ve Waterlow verilerine göre serebral palsili çocuklarda ek olarak istenen ağırlık kazanımı 5 kkal/kg'ın uygun olduğu belirtilmektedir. İstenen ağırlık kazanımı yaşa göre boy uzunluğu veya NCHS'nin 10 yaş ve üzeri çocuklar için geliştirilen büyüme-gelişme eğrileri ile belirlenir. ${ }^{31}$

Diğer bir formül ise Rieken ve ark. ${ }^{22}$ tarafindan ambule olmayan, okul çağı çocukları için geliştirilen iki eşitliktir. İlk eşitlikte, BMH'nın belirlenmesinde sıklıkla
Schofield denklemi kullanılır, diğer eșitlikte ise total vücut suyunun ölçümü kullanılır. Bu temel hesaplamada fiziksel aktivite düzeyi, kaba motor testi seviyesi ve SP'nin türüne göre bir düzeltme yapılır ( Tablo3).

Serebral palsili bireyler kendi aralarında bir takım farklılıklar göstermekte olup; bazı bireyler hipotoni sonucu hipermetabolik olabilirken bazıları artan kas tonusu sonucu hipermetabolik olabilmektedir.

Enerji harcaması için kullanılan eşitlikler ile indirekt kalorimetre ile ölçülen enerji harcaması değerlerini karşılaștırmak amaciyla Hong Kong Medical Center'in Gelişimsel Engel Ünitesinde yatan spastik 15 SP'li çocuk ile bir çalışma yapılmıştır. İndirekt kalorimetre ile ölçülen enerji harcaması, vücut yüzey alanını içeren formülle (Vücut Yüzey Alanı x Standart metabolizma hızı x 24 saat) hesaplanan enerji; RDA önerileri (50. percentilin boya göre vücut ağırlığ $\mathrm{x}$ yaşa göre olması gereken vücut ağırlığı (kg) ve SP'li (Ciddi aktivite kısıtllılığında $11.1 \mathrm{kkal} / \mathrm{cm}$, orta düzeyde aktivite kısıtlılığında $13.9 \mathrm{kkal} / \mathrm{cm}$ ) hastalar için geliştirilen eşitlikle hesaplanmış ve bu değerler karşılaştırılmıştır. Ayrıca günlük besin alımları da kaydedilmiştir. Sonuçta, enerji gereksinmesi düşükten yükseğe doğru sırasıyla; indirekt kalorimetre ile ölçülen < ölçülen vücut yüzey alanı kullanılarak hesaplanan $<$ SP hastalarına özel formülle hesaplanan<RDA enerji önerisi olarak bulunmuştur. Yani RDA'ya göre hesaplanan enerji gereksinmesi en fazla, indirekt kalorimetre ile ölçülen ise en düșük olarak bulunmuştur $(\mathrm{p}<0.001)$. Diyetle alınan günlük enerji ile günlük ortalama enerji harcaması arasında anlamlı bir fark bulunmamıştır. ${ }^{24}$

Kennedy Ensititüsü'nde yatan, bir haftadan uzun süre tüple beslenen, yaşları 9 ay-18 yaş arasında olan 30 SP'Ii birey ile yapılan diğer bir çalışmada; enerji gereksiniminin belirlenmesinde kullanılan iki metodun karşılaştırılması hedeflemiştir. Bunlardan biri vücut ağırlığı, kas tonusu ve aktivite değerini içeren formüldür (Krick metodu), diğeri ise yaşa göre RDA önerisini baz alan değerlendirmedir. RDA metodu ağır SP'li çocuklarda gereksinmenin üzerinde 
tahmine neden olmaktadır. Krick metodu bu çalışmada RDA'ya göre enerji gereksiniminin belirlenmesinde daha üstün bulunmuştur. ${ }^{21}$ $\mathrm{Bu}$ çocuklarda yağsız doku kütlesinin azalması enerji gereksinimini değiștirebilir.
Diğer bir neden ise bu çocukların aktivite düzeylerinin çok düşük olması olabilir. Endokrin bozukluklar (örneğin hipotroidi) ve nöral faktörler (şiddetli hidrosefali vb) de enerji gereksinimini değiștirebilmektedir.

Tablo 3: Schofield Denklemine ve Total Vücut Suyunun Ölçümüne Dayanan Yeni Eșitlikler22 (KMFSS: Kaba motor fonksiyon sınıflama sistemi, TEH: Toplam enerji harcaması)

\begin{tabular}{|c|c|c|}
\hline & $\begin{array}{l}\text { Schofield denklemine } \\
\text { dayanan model }\end{array}$ & $\begin{array}{l}\text { Çift etiketli su metotundan total vücut } \\
\text { suyu ölçümünü kullanan model }\end{array}$ \\
\hline \multicolumn{3}{|r|}{ r } \\
\hline \multicolumn{3}{|l|}{$3-9($ yll $)$} \\
\hline \multirow[t]{2}{*}{ Erkek } & BMH: & \\
\hline & 0.095*ağırlık(kg)+2.110 & \\
\hline \multirow[t]{2}{*}{ Kadın } & BMH: & \\
\hline & $0.085^{*}$ ağırlık(kg)+2.033 & \\
\hline \multicolumn{3}{|l|}{ Yaş } \\
\hline \multicolumn{3}{|l|}{$10-18$ (yıl) } \\
\hline \multirow[t]{2}{*}{ Erkek } & $\mathrm{BMH}:$ & \\
\hline & $0.074 *$ ağırlık(kg)+2.754 & \\
\hline \multirow[t]{2}{*}{ Kadın } & BMH: & \\
\hline & 0.056*ağırlık(kg)+2.898 & \\
\hline \multicolumn{2}{|l|}{ (kcal) } & $60.7 *^{*}$ total vücut suyu $(\mathrm{kg})$ \\
\hline \\
\hline Genel düzeltmeler & $-280 \mathrm{kcal}$ & +175 kcal \\
\hline $\begin{array}{l}\text { Yüksek } \\
\text { derecede hareket }\end{array}$ & +222 kcal & +344 kcal \\
\hline $\begin{array}{l}\text { Seviye } 4 \\
\text { (KMFSS) }\end{array}$ & +431 kcal & +194 kcal \\
\hline
\end{tabular}

$\mathrm{Bu}$ heterojen grupta enerji gereksinmesi; mobilizasyon durumu, kas tonusu, aktivite düzeyi, değișen metabolizma ve gelişim göz önüne alınarak bireysel olarak hesaplanmalıdır. İndirekt kalorimetre ile ölçüm tercih edilmelidir. Ancak indirek kalorimetre pahalı bir yöntem olup her merkezde bulunmamaktadır. ${ }^{33} \mathrm{Bu}$ nedenle bu özel grup için öneilen eşitliklerin kullanımı veya günlük enerji harcamasının saptanmasinda akseloremetre veya fiziksel aktivite kaydı yöntemlerinin kullanımı da sözkonusudur.

Ayaktan tedavi alan 20 SP'li çocuk ve onlarla yaş ve cinsiyet açısından uyumlu 20 sağlıklı çocuk üzerinde bir çalışma yapılmıştır. ${ }^{34}$ Çalışmaya KMFSS sinıflamasına göre, seviye bir ve iki düzeyindeki çocuklar dahil edilmiştir.
Caltrac akselerometre, (2 gün hafta içi, ikigün hafta sonu) dört gün boyunca takılmış, aynı zamanda fiziksel aktivite günlüğü tutulmuştur. Caltrac akselerometre ile günlük toplam enerji harcaması; SP'li grupta 963,75-2250,25 kkal/gün, kontrol grubunda ise, 1025,75-2820,25 kkal/gün arasında kaydedilmiştir. Ayrıca fiziksel aktivitenin enerji harcamasının; SP'li grupta 74.75$553,50 \mathrm{kkal} /$ gün, kontrol grubunda ise 169$1338,75 \mathrm{kkal} /$ gün arasında olduğu saptanmıștır. Serebral palsili grubun hem günlük toplam enerji harcaması, hem de fiziksel aktiviteden oluşan enerji harcaması, kontrol grubundan anlamlı olarak düşük bulunmuştur $(\mathrm{p}<0.05)$. Çalışma sonucunda, aktivite günlüğünün günlük enerji harcamasını belirlemede en az akselerometre kadar yetkin olduğu saptanmıştır. 
İki yüz ağır SP'li çocuk üzerinde yapılan çalışma sonucunda vücut ağırlığı ve bileşimindeki değişikliklerin saptanmasında biyoelektrik impedans analiz (BIA) kullanılmasının beslenme durumunun değerlendirilmesinde uygun olduğu, ayrıca diyetle yeterli alımı değerlendirmede vücut ağırlığı kazanımının izlenmesinin iyi bir yöntem olduğu bildirilmiştir. ${ }^{15}$

Enerji ihtiyacını hesaplamak için ilaçların enerji harcaması üzerindeki etkisini dikkate almak önemlidir. Örneğin, hipertonisi olan bireyler için kas tonusunu azaltan Trihexyphenidyl ya da Baklofen gibi ilaçların kullanılması genellikle enerji harcamasını azaltır. Ağırlık yakından izlenmeli ve istenmeyen vücut ağırlı̆̆ değişikliklerini önlemek için enerji alımı ayarlanmalıdır. Risperidon gibi antipsikotik ilaçların yan etkisi olarak iştah artışının aşırı kilo alımına neden olabileceği göz önünde bulundurulmalıdır. 35

\section{Sonuç}

Serebral palsili çocuklarda beslenme, medikal tedavinin bir parçasıdır, tedavi programı her hastanın gereksinimine göre düzenlenmeli ve ailenin de içinde yer alacağ ekip çalışması yaklaşımı benimsenmelidir. $\mathrm{Bu}$ çocuklara yeterli büyüme ve gelişmenin sağlanması, yaşam kalitesinin iyileștirilmesi için erken nutrisyonel müdahale ile uygun destek verilmelidir.

Vücut kompozisyonu ve motor aktiviteleri normalden farklı olan SP'li çocuklarda, enerji gereksinimi değişiklik gösterdiği için ağır serebral palsili çocukların enerji ihtiyacı, sağlıklı yașıtlarının enerji ihtiyacının ancak \% 60-70'i kadar olduğu dikkate alınmalıdır.

Enerji ihtiyacının belirlenmesinde kullanılan pek çok yöntem SP'li çocukların ihtiyaçlarını göz ardı etmektedir. Enerji gereksinmesi; mobilizasyon durumu, kas tonusu, aktivite düzeyi, değișen metabolizma ve gelișim göz önüne alınarak bireysel olarak belirlenmelidir. Bütün bu faktörleri içeren Krick metodu SP'li çocuklar için enerji ihtiyacını belirlemede en uygun yöntem olmasına rağmen klinikte uygulanması zordur ve henüz tam olarak doğrulanmamıștır. Çift etiketli su ve indirekt kalorimetre gibi bazal metabolizma hızı ölçüm yöntemleri bireysel olarak enerji gereksinimlerini belirlenmesinde daha doğru sonuç vermektedir; ancak pahalı ve kompleks yöntemlerdir. Bu grupta yeterli enerji alımını değerlendirilmesinde yardımcı olacak yöntemlerden en pratik olanı diyet tedavisi ile birlikte vücut ağırlığı kazanımının izlenmesidir.

Serebral palsili çocuklarda enerji harcamasının tahmininde kullanılan eșitlikler geliștirilmiș olmakla birlikte indirek kalorimetre ölçümleriyle uyumlu eşitliklerin geliştirilmesine ihtiyaç bulunmaktadır.

\section{Kaynaklar}

1. Yakut A. Serebral Palsi. Aysun S (ed). Çocuk Nöroloji. Ankara: Alp Ofset Matbaacılık Makine Sanayi ve Ticaret Ltd. Şti 2006:420-465.

2. Bax M., Goldstein M., Rosenbaum P., Leviton A., Paneth N., Dan B., Jacobsson B., Damiano D., Proposed Definition and Classification of Cerebral Palsy. Developmental Medicine and Child Neurology 2005; 47(8):571-576.

3. Rosen M.G., Dickinson J.C., The Incidence of Cerebral Palsy. American Journal of Obstetrics Gynecology 1992;167(2), 417-423.

4. Serdaroğlu A., Cansu A., Özkan S., Tezcan S. Prevalance of Cerebral Palsy in Turkish Children Between the Ages of two and 16 years. Developmental Medicine and Child Neurology 2006;48;413-416.

5. Șimșek T.T., Tuç G. Serebral Palsili Çocuklarda Beslenme Problemleri ve Büyüme Üzerine Etkisi. J Curr Pediatr 2014;12:73-80.

6. Bell KL., Samson-Fang L. Nutritional Management of Children With Cerebral Palsy. European Journal of Clinical Nutrition 2013;67:13-16.

7. Morris C. Orthotic Management of Children with Cerebral Palsy. Journal of Pediatric Orthopedics 2002;14:150-158.

8. Bandini L.G., Puelzl-quinn H., Morelli J.A., Fukagawa N.K. Estimation of Energy 
Requirements in Persons With Severe Central Nervous System Impairment. The Journal of Pediatrics 1995;126(5 Pt 1):828832.

9. Cully W., Middleton,T.A. Caloric Requirements of Mentally Retarded Children With and Without Motor Disfunction. Journal of Pediatrics 1969;75:380-384.

10. MacLennan A. A Template for Defining a Causal Relation Between Acute Intrapartum Events and Cerebral Palsy: International Consensus Statement. British Medical Journal 1999;(319)1054-1059.

11. Bialik G.M., Givon U. Cerebral Palsy: Classification and Etiology. Acta Orthopaedica et Traumatologica Turcica 2009;43(2)77-80.

12. Rosenbaum P.L., Walter S.D., Hanna S.E., Palisano R.J., Russel D.J., Raina P., Wood E, Bartlett DJ, Galuppi BE, Prognosis For Gross Motor Function in Cerebral Palsy: Creation of Motor Development Curves. The Journal of the American Medical Association 2002; 288:1357-63.

13. Rosenbaum P., Paneth N., Leviton A., Goldstein M., Bax M., Damiano D., Dan B., Jacobsson B. A Report: The Definition and Classification of Cerebral Palsy April 2006. Developmental Medicine Child Neurology Suppl 2007;109:8-14.

14. Reyes A.L., Cash A.J., Green S.H., Booth I.W. Gastroeosophageal Reflux in Children With Cerebral Palsy. Child Care Health Development 1993;19:109-118.

15. Marchand V., Motil K.J. Nutrition Support for Neurologically Impaired Children: A Clinical Report of the North American Society for Paediatric Gastroenterology, Hepatology and Nutrition. Journal of Paediatric Gastroenterology and Nutrition 2006;43:123-135.

16. Penagini F., Mameli C., Fabiano V., Brunetti D., Dilillo D., Zuccotti G.V. Dietary Intakes and Nutritional Issues in Neurologically Impared Children. Nutrients 2015; 13;7(11):9400-9415.

17. Garcia-Contreras A.A., Vasquez-Garibay E.M., Romero-Valerde E., Ibarra-Gutierrez A.I., Troyo-Sanroman R. Energy Expenditure in Children With Cerebral Palsy and
Moderate/Severe Malnutrition During Nutritional Recovery. Pediatria 2015;31(5):2062-2069.

18. Sullivan P.B. Gastrointestinal Disorders in Children With Neorodevelopmental Disabilities. Developmental Disabilities Research Reviews 2008;4:128-136.

19. Tomoum H.Y., Badawy N.B., Hassan N.E., Alian K.M. Anthropometry and Body Composition Analysis in Children With Cerebral Palsy. Clinical Nutrition 2010;29:477-481.

20. Kilpinen Loisa P., Pihko H., Vesander U., Paganus A., Ritanen U., Makitie O. Insufficient Energy and Nutrient Intake in Children With Motor Disability. Acta Paediatrica 2009; 98:1329-1333.

21. Krick J., Murphy EP., Markham F.B.J., Shapiro K.B. A Proposed Formula For Calculating Energy Needs of Children With Cerebral Palsy. Developmental Medicine and Child Neurology 1992;34:481- 487.

22. Rieken R., Johannes B., Schierbeek H., Willemsen S.P., Calis E.A.C., Tibboel D., Evenhuis H.M., Penning C. Measuring Body Composition And Energy Expenditure in Children With Severe Neurologic Impairment and Intellectual Disability. American Journal of Clinical Nutrition 2011;94(3):759-766.

23. Walker J.L., Bell K.L., Boyd R.N., Davies P.S.W. Energy Requirements in Preschoolage Children With Cerebral Palsy. American Journal of Clinical Nutrition 2012;96:13091315.

24. Lee SP., Cheung KM., Ko CH., Chiu CH. Is There an Accurate Method to Measure Metabolic Requirement of Institutionalized Children With Spastic Cerebral Palsy. Journal of Enteral and Parenteral Nutrition 2011; 35(4):530-534.

25. Hayes M., Chustek M., Wang Z., Gallagher D., Heshka S., Spungen A. DXA: Potential For Creating A Metabolic Map of Organ Tissue Resting Energy Expenditure Components. Obesity Research 2002;10(10):969-977.

26. Dickerson N.R., Brown R.O., Gervasio J.G. Measured Energy Expenditure of Tube-fed Patients With Severe Neurodevelopmental Disabilities. The Journal of The American 
College of Nutrition 1999;18:61-68.

27. Vernon-Roberts A., Wells J., Grant H. Gastrostomy Feeding in Cerebral Palsy: Enough and No More. Developmental Medicine and Child Neurology. 2010;52(12):1099-1105.

28. DuBois D. DuBois E.F. A Formula to Estimate The Approximate Surface Area if Height and Weight be Known. Archives of Internal Medicine 1916;17:863-71.

29. Wang Y., Moss J., Thisted R. Predictors of body surface area. Journal of Clinical Anesthesia 1992;4(1):4-10.

30. Fleish P.A. La Metabolisme Basal Standard et sa Determination Aumoyen du 'Metabocalculator'. Helvetica Chimia Acta 1951;18:23-44.

31. Payne P.R., Waterlow J.C. Relative Energy Requirements For Maintenance, Growth and
Physical Activity. Lancet 1971; 24;2(7717):210-211.

32. Öztürk B., Ertem D. Nörolojik Sorunu Olan Çocukta Beslenme Sorunları. Soru ve Cevaplarla Çocuk Beslenmesi. Akademi Yayınevi, 2015.

33. Veugelers R., Penning C., Gulik M.E., Tibboel D., Evenhuis E. Feasibility of Bioelectrical Impedance Analysis in Children With a Severe Generalized Cerebral Palsy. Nutrition 2006;(22):16-22.

34. Küçük Ö.E. Serral Palsili Çocukların Fiziksel Aktivite Seviyelerinin Belirlenmesi ve Normal Gelişim Gösteren Çocukların Fiziksel Aktivite Seviyeleri ile Karşılaştırılması. Hacettepe Üniversitesi Sağlık Bilimleri Enstitüsü 2012.

35. Writtenbrook W. Parrish CR. Nutritional Assessment And Interventoin in Cerebral Palsy. Practical Gastroenterology. 2011. 